\title{
Antimicrobial Efficacy of Immersion 0.5\% Sodium Hypochlorite And 2\% Glutaraldehyde Disinfectants on Alginate Impressions
}

\author{
Eddy Dahar,JasminKaur \\ Department of Prosthodontics \\ Faculty of Dentistry, UniversitasSumatera Utara, Padang Bulan, Medan-20155, Indonesia \\ Jl. Alumni No. 2 Kampus USU, Medan 20155, Sumatera Utara, Indonesia
}

\begin{abstract}
Dental impressions often carry microorganisms that may cause cross infection from patients to dental staff. The control of cross infection is an imperative issue when dealing with dental impression materials in Dentistry and the lack of procedures for its control is currently a real problem. The aim of this study was to evaluate the antimicrobial effectiveness of 0,5\% sodium hypochlorite and $2 \%$ glutaraldehyde immersion of alginate.Thirty edentulous patients were selected for the present study. Maxillary ridge impressions were taken out in 30 patients with alginate and was randomly divided into two groups containing 15 impressions each group, each impression was swabbed and incubated on nutrient agar culture media. This constituted the control group. Group A impressions were immersed in 0.5\% sodium hypochlorite and group B impressions were immersed in 2\%glutaraldehyde. All impressions received the similar disinfectant treatment. After 10 minutes the impressions were reswabbed and incubated for 24 hours and microbial colony count was carried out. It was observed that $2 \%$ glutaraldehydeis more efficient in reducing the number of bacterial colony count compared to $0.5 \%$ sodium hypochlorite. $2 \%$ glutaraldehyde eliminated $46.74 \%$ of bacteria colony count while $0.5 \%$ sodium hypochlorite eliminated $43.33 \%$ of bacteria colony count. Dental impression materials can act as vectors transmitting a significant amount of microorganisms. It was concluded that $0.5 \%$ sodium hypochlorite and $2 \%$ glutaraldehyde was stistically equally effective in reducing the number of bacterial colony count. 2\% glutaraldehyde was found to be marginally more effective than $0.5 \%$ sodium hypochlorite on alginate impressions.
\end{abstract}

Keywords:Alginate impression, Disinfection, Sodium hypochlorite, Glutaraldehyde

\section{I.Introduction}

There are many types of microorganisms in the human oral cavity, such as bacteria, viruses, fungi and others. In the field of dentistry, it is very prone to cause cross contamination infections. Therefore dental care providers as well as dental assistants, staff and laboratory technicians are possible targets of contamination. Many infectious disease can be transmitted during dental treatment, including tuberculosis, syphilis, hepatitis A, $\mathrm{B}, \mathrm{C}$ and acquired immunodeficiency syndrome (AIDS). According to various studies, dental impressions are one of the main source of cross infection between dentists, nurses, patients and laboratory personnel.Dental impressions consistof taking into the mouth and is able to register the anatomical relief of the area desired that is dimensionally stable. The impression then displays the anatomy of the impressed area. During this procedure, the material has contact with saliva and blood, which are sources of contamination, and caries a great number ofmicroorganisms of the flora upon removal from the mouth.

New researches have shown that $64 \%$ of materials sent to dental laboratories are infected by various types of harmful microorganisms on them. In dentistry there are several types of impression materials that have as main features such as accuracy, elastic recovery, dimensional stability, flow, flexibility, workability, hydrophilicity, a long shelf-life, patient comfort and economics. Of all materials used for impressions, hydrocolloids and elastomers are the most important in this field. The hydrocolloids are subdivided into reversible and irreversible. Alginate is an example of irreversible hydrocolloid and is the most commonly used material in dentistry since it is easy to manipulate, does not imply specialized equipment and is low-priced. As irreversible hydrocolloids are composed of $80 \%$ water they are subject to the phenomena of imbibition (absorption of water) and syneresis (evaporation of water)

The International Dental Federation (IDF) insists on disinfecting all impressions taken from patients before sending them to laboratories. Also the American Dental Association (ADA) has advised all dental stuffs to disinfect patient's impression trays. The most common chemical disinfectants which are used by dentist, are hypochlorites, biguanides, aldehydes, alcohols, phenols and chlorhexidine. Among these $0.5 \%$ sodium hypochlorite and $2 \%$ glutaraldehyde have been considered effective, a good surface disinfectant, non-irritating and efficient againts wide-spectrum microorganisms. Both sodium hypochlorite and glutaraldehyde act in the 
fixation of the cell membrane, blocking the release of cellular components and consequently killing the microorganisms.

There are two disinfectant techniques for impression material, immersion and spraying. Disinfection by immersion allows the solution to contact with all surfaces of the impression. Spraying has a lower probability of distortion than the other technique but it may not reach all surfaces. Yet, the antimicrobial activity of both techniques is considered similar.The objective of this study was to evaluate the antimicrobial efficacy of $0.5 \%$ sodium hypochlorite and $2 \%$ glutaraldehyde disinfecting solutions in removing microorganisms from the surface of alginate impression material.

\section{Methods}

Each of the patient was evaluated by a medical and dental history. Treatment plan and study procedure were explained to the patient. After confirmation of their full cooperation, 30 subjects of them were finally selected. Study procedure consisted of prosthodontic laboratory procedure and microbiological laboratory procedure. The impressions were made with alginate (Aroma Line Plus Normal Set,Tokyo-Japan) which was manipulated according to the manufacturer's instructions. The disinfectants used in this study were $0.5 \%$ sodium hypochlorite and $2 \%$ glutaraldehyde. Suitable impression trays were used for the impression, total of 30 impressions of maxillary ridges were taken out in 30 patients which were randomly divided into two groups of each containing 15 impressions.

After removal from the mouth the impression was washed with running tap water for 15 seconds to remove excess saliva. Prior to disinfectant, the impression that was used for the study constituted the control group and the same was used as test group after disinfection. For this purpose, each of the impressions was numbered on the back of it.

\section{Pre disinfectant microbial colony count.}

For this purpose the surface of each of the impression was swabbed with sterile needle wire and was applied into nutrient broths. Nutrient broths were vortexed for 30 seconds and then $10 \mu \mathrm{lform}$ each suspension was inoculated onto nutrient agar media using a micropipette and incubated for 24 hours at $37^{\circ} \mathrm{C}$. After 24 hours, the microbial colony count was then carried out using a colony counter.

\section{Disinfectant procedure.}

Group A and Group B impressions were reused in disinfection procedures. Group A included 15 impressions immersed in a beaker containing $0.5 \%$ sodium hypochlorite disinfectant for 10 minutes. Group B included 15 impressions immersed in a beaker containing $2 \%$ glutaraldehyde disinfectant for 10 minutes.

\section{Post disinfectant microbial colony count.}

After a period of 10 minutes, each of the impressions was removed from the beaker and again swabbed with sterile needle wire and was applied onto nutrient broths. Nutrient broths were vortexed for 30 seconds and then $10 \mu \mathrm{l}$ from each suspensions was inoculated onto nutrient agar media using a micropipette and incubated for 24 hours at $37^{\circ} \mathrm{C}$. After 24 hours, the microbial colony count was then carried out using a colony counter.

All 30 impressions were treated in similar manner. The results were recorded, analyzed and compared with the control and were subjected to statistical analysis.

\begin{tabular}{|c|c|c|c|}
\hline Groups & $\mathbf{n}$ & $\begin{array}{c}\text { Difference in total } \\
\text { bacteria count } \\
(\mathrm{CFU} / \mathrm{ml})\end{array}$ & \multirow{2}{*}{$\mathrm{p}$} \\
\cline { 3 - 3 } & & $\overline{\mathrm{x}} \pm \mathrm{SD}$ & \\
\hline $\begin{array}{c}\text { 0,5\% Sodium } \\
\text { Hypochlorite }\end{array}$ & 15 & $\begin{array}{c}75,46 \times 10^{2} \pm \\
1,50 \times 10^{2}\end{array}$ & \multirow{2}{*}{0,342} \\
\hline $\begin{array}{c}\text { 2\% } \\
\text { Glutaraldehyde }\end{array}$ & 15 & $\begin{array}{c}81,46 \times 10^{2} \pm \\
23,99 \times 10^{2}\end{array}$ & \\
\hline
\end{tabular}

\section{Results}

According to table above, the disinfection action of the two mentioned disinfectants showed no significant difference between groups after 10 minutes immersion ( $\mathrm{P}$ value $>0.05)$ but it was proven that $2 \%$ glutaraldehyde is more effective is reducing the number of total bacteria count CFU/ML. The difference in

DOI: $10.9790 / 0853-1606131114 \quad$ www.iosrjournals.org $\quad 12 \mid$ Page


reduction of total bacteria count CFU/ML (Colony Forming Unit) with $0.5 \%$ sodium hypochlorite was 75,46 x $10^{2} \mathrm{CFU} / \mathrm{ML}$ and with $2 \%$ glutaraldehyde was $81,46 \times 10^{2} \mathrm{CFU} / \mathrm{ML}$.

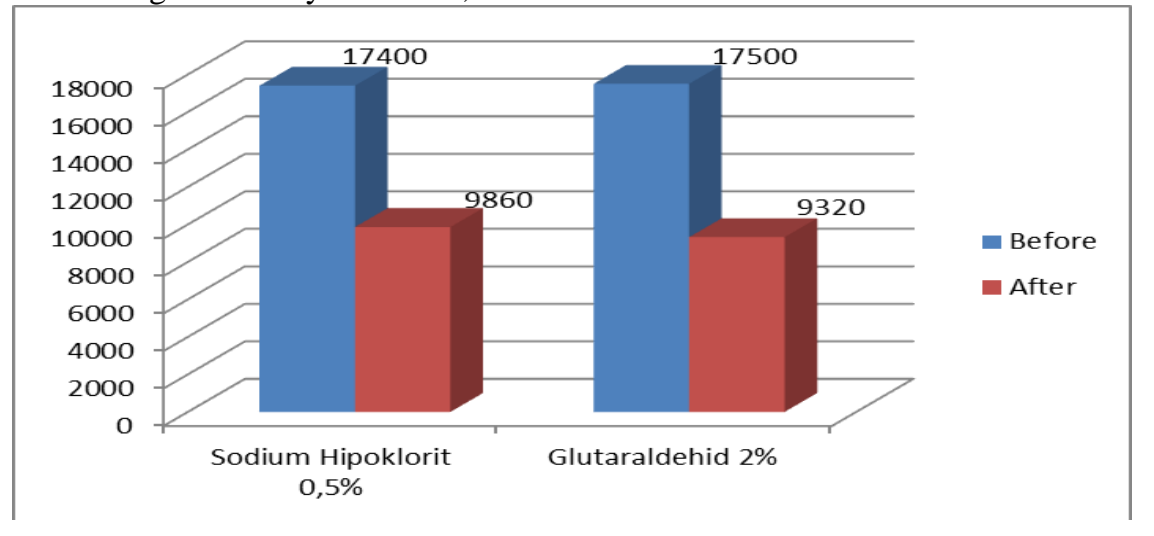

It was also proven graphically that $2 \%$ glutaraldehyde is more efficient in reducing the number of bacterial colony count compared to $0.5 \%$ sodium hypochlorite.From the graph above, it was observed that $2 \%$ glutaraldehydeeliminated $46.74 \%$ of bacteria colony count while $0.5 \%$ sodium hypochlorite only eliminated $43.33 \%$ of bacteria colony count.

\section{Discussion}

Minimizing the risk of disease transmission in the dental workplace has today become a high priority for the dental profession. Dentist are responsible for prevention of cross infection in dental clinic, including proper impression disinfection before sending to dental laboratory. Studies have documented the presence of bacteria on the impression and dental prothesis sent to laboratory. Hence, dental impressions should always be disinfected to prevent infection. These disinfectants can beused either in the form of immersion or as spray disinfectant. Spray disinfectant though effective, they are not as satisfactory as immersion, considering their adverse effect where it is not capable of disinfecting all surfaces effectively and also cannot cover all undercuts. Considering this, immersion disinfectants were selected to study their antimicrobial effect. Among the two impression materials used for edentulous impression it has been reported that alginate impression material has an intrinsicretentive potential for microbes and is therefore potentially more difficult to disinfect. It has been reported bySamaranayake et al that alginate impression carry three to four times more organisms than impression compound. This is yet another reason for including alginate impression in this study.

The data collected was based on the colony forming units in the culture media. They were counted with colony counter and the counts were expressed under the standard method of recording microbial colony count (CFU count). This study was designed to evaluate the antimicrobial efficacy of $0.5 \%$ sodium hypochlorite and $2 \%$ glutaraldehyde disinfecting solution in removing microorganisms from the surface of alginate impression material. Immersion disinfection of impressions were performed with a 10 minutes application time. Total of 30 impressions were collected ( 01 from each subject). Impression were divided into two groups, each consisted of 15 impressions. The mean bacterial colony count for group A was $75.46 \times 10^{2} \pm 1,50 \times 10^{2} \mathrm{CFU} / \mathrm{ML}$ and for group B was $81.46 \times 10^{2} \pm 23.99 \times 10^{2}$ CFU/ML. The mean bacterial count difference between groups was statistically not significant $(\mathrm{p}>0,05)$.

In westerholm study, it was showed that sodium hypochlorite can absolutely $99.99 \%$ prevent the growth of staphylococcus aureus. In another study by Ghahramanloo and colleagues (2009), spraying $0.525 \%$ sodium hypochlorytecould desinfect samples effectively (96.6\%) in 10 minutes. Bustos et al (2010) used 2\% glutaraldehyde solution with 5 minutes application time to disinfect alginate impression which reduced microbial count to mean $\mathrm{cfu}=0.02 \times 10^{3} \pm 0.04 \times 10^{3}$ from the untreated control groups count mean cfu $=0.71 \mathrm{x}$ $103 \pm 1.05 \times 10^{3}$. Egusa et al (2008) described a $42.8 \%$ reduction of microbial colony count on alginate impressions surface when they were treated with $2 \%$ glutaraldehyde solution for 10 minutes where as only $15.8 \%$ colony count reduction achieved when rinsed with tap water. The antimicrobial efficiency of $2 \%$ glutaraldehyde solution is also supported by this present study. HimanshuAeran et al (2010) concluded that the antimicrobial activity of spray disinfectant with $2 \%$ glutaraldehyde and $0.5 \%$ sodium hypochlorite was statistically to be equally effective both againts gram positive and gram negative organisms. Look et al (1990) concluded that sodium hypochlorite and glutaraldehyde were better than iodophors. Efficacy of sodium hypochlorite was almost similar to glutaraldehyde. The results are similar to a study conducted by Jennings et al (1991) concluded that glutaraldehyde and sodium hypochlorite exhibited comparable microbiocidal activity.

The data of this study showed that $0.5 \%$ sodium hypochlorite eliminated $43.33 \%$ of bacteria on alginate impression and $2 \%$ glutaraldehyde eliminated $46.74 \%$ of bacteria on alginate impression. Since so many dentist 
are concerned about viruses such as HIV and HBV, further studies should be conducted to find an effective method to eradicate these kinds of pathogens.

\section{Conlcusion}

According to the results of the present study, it can be concluded that both disinfectant agents effectively disinfected alginate impressions. The antimicrobial activity of immersed disinfectants of $0.5 \%$ sodium hypochlorite and $2 \%$ glutaraldehydewas found to be equally effective. $2 \%$ glutaraldehyde was marginally more effective than $0.5 \%$ sodium hypochlorite on alginate impression. Hence, routine disinfection of impessions using either one of the disinfectantis preferred to prevent cross infection in dental practice.

\section{Reference}

[1]. SunotoRatna I. TindakanPencegahanPenularanPenyakitInfeksiPadaPraktekDokter $\quad$ Gigi. FakultasKedokteran Gigi UniversitasTrisakti. Jakarta, 2011; 4: 2-16.

[2]. Sousa CJ, Tabaio MA, Silva A,dkk. The effect of water and sodium hypochlorite disinfection on alginate impressions. Elsevier Doyma 2013; 54(1): 8-12.

[3]. Ahsan MR, Islam KZ, Begum J. Study on antimicrobial effect of disinfecting solutions on alginate impression materials. Dent Coll J 2013; 3(1): 18-23.

[4]. Sari RF, Parnaadji $\quad$ R, $\quad$ Sumono $\quad$ A. PengaruhTeknikDesinfeksidenganBerbagaiMacamLarutanDesinfektanpadaHasilCetakanAlginatterhadapStabilitas Dimensional. JurnalPustakaKesehatan 2013; 1(1): 29-34.

[5]. Badrian H, Ghasemi E, Hosseini N dkk. The Effect of Three Different Disinfection Materials on Alginate Impression by Spray Method. ISRN Dentistry 2012; $1-5$.

[6]. Haralur BS, Al-Dowah OS, Gana SN, Al-Hytham A. Effect of alginate chemical disinfection on bacterial count over gypsum cast. 4 th ed., J Adv Prostodont2012: 84-8.

[7]. Kollu S, Hedge V, Pentapati CK. Efficacy of Chlorhexidine in Reduction of Microbial Contamination in Commercially Available Alginate Materis-In-Vitro Study. Global Journals Inc 2013; 13(2).

[1]. Collins FM. Disinfecting Impressions for Infection Prevention. A Peer Reviewed 2013; 16-8.

[2]. Nallammuthu NA, Braden M, Patel MP. Some aspects of the formulation of alginate dental impresson materials- Setting characteristics and mechanical properties. 28 th ed., Elsevier $2012: 756-762$.

[3]. Boksman L, Tousignant G. Alginate Substitutes Rionale for Their Use. CDT: Dentistry Today 2009; 28(4) : 57-60.

[4]. Gambardella GE, Johnson JR. Alginate Impression and Diagnostic Study ModelTechniques.http://www.dentalcare.com/enUS/dentaleducation/continuing-education/ce378/ce378.aspx. (February 3,2014)

[5]. Silva SM, Salvador MC. Effect of the disinfection technique on the linear dimensional stability of dental impression materials. AAppl Oral Sci 2004; 12(3): 244-9.

[6]. Ferreira FM, Novais V, Sinomoto PC, Soares C, Fernandes A. Evaluation of Knowledge About Disinfection of Dental Impressions in Several dental Schools. Rev Odontol Bras Central 2010; 19(51): 285-9

[7]. PalenikCJ.DentalLaboratoryAsepsis.http://www.dentistrytoday.com/infection-control/1325 (31 December 2004).

[8]. Amin W, Al-Ali M, Tarawneh S, Taha S dkk. The Effects of Disinfectants on Dimensional Accurary and Surface Quality of Impression Materials and Gypsum Casts. J Clin Med Res 2009; 1(2): 81-9.

[9]. Sumadhi S. PerubahanDimensiHasilCetakan Gigi dan Mulut.USU Press 2010; 71-81.

[10]. U Sukhija, M Rathee, N Kukreja, Khindria S dkk. Efficacy of Various Disinfectants on Dental Impression Materials. The Internet Journal of Dental Science 2009; 9(1).

[11]. Moura C, Moura WL, Franca F, Martins G dkk. Disinfection of irreversible hydrocolloid impressions with sodium hypochlorite steam :Assesment of antimicrobial efficacy. Rev Odonto 2010; 25(2) : 182-7.

[12]. Aeran H, Jurel S, Dhobhal A. Antimicrobial efficacy of spray disinfectants on dental impressions. Indian Journal of Dental Science $2010 ; 2(6)$ 10-3.

[13]. Szymanska j. Microbiological risk factors in dentistry. Current status of knowledge. Ann agric environ med 2005; 12, 157-163

[14]. Slots J, Slots H. Bacterial and viral pathogens in saliva. : disease relationship and infectious risk. Periodontology 2000; vol 55 2011, 48-69.

[15]. Roberts JR. The Causes of Infection. https://suite.io/john-richard-roberts/qa42qr (10 October 2007).

[16]. Kohn W, Collins A, Cleveland J, Harte J, Eklund K dkk. Guidelines for Infection Control in Dental Health-Care Settings. MMWR 2003; 52(17) : 1-29.

[17]. MifflinH.CrossInfection.http://medicaldictionary.thefreedictionary.com/cross+infection; 2009.

[18]. Pankhurst CL, Coulter WA. Infection Prevention and Control In Dentistry. New Delhi,India: Aptara., 2009: 1-15.

[19]. Cherney K. Cross Infection. http://www.healthline.com/health/cross-infection. ( 5 June 2013).

[20]. Georgescu CE, Skaug N, Patrascu I. Cross Infection in Dentistry. RoumBiotechnol. Lett 2002; 7(4) : 861-8.

[21]. Royal College of Dental Surgeons of Ontario. Infection Prevention and Control in the Dental Office, 2010: 4-37.

[22]. Kohli A, Puttaiah R. Infection Control And Occupational Safety Recommendations For Oral Health Professionals. Dental Council of India, 2007: 1-12.

[23]. Rampal N, Pawah S, Kaushik P. Infection Control In Prostodontics. J Oral Health Comm Dent 2010; 4(1) : 7-11.

[24]. Malone B. Good Practice in Infection Prevention and Control. Royal College of Nursing 2005; 4-8.

[25]. DvorakG.Disinfection101.http://www.cfsph.iastate.edu/Disinfection/index.php ( February 2005).

[26]. Gamage B. A Guide to Selection and Use of Disinfectants. BC Centre for Disease Control,2003; 1-10.

[27]. David, Munadziroh E. Perubahanwarnalempengrinakrilik yang direndamdalamlarutandesinfektan sodium hipokloritdanklorhexidin. Maj. Ked. Gigi (Dent. J) 2005; 38(1) : 36-40.

[28]. BA Mary. Combating Cross Contamination. Inside Dental Technology.2013. M Belinda. Protocols regarding Infection Control. Associated Dental Products. 2010.

[29]. Hatrick CD, Eakle WS, Bird W. Dental Materials Clinical Applications for Dental Assistants and Dental Hygienists. 2 nd ed. Elsevier 2011; 179-182.

[30]. Powers JM, Wataha JC. Dental Materials properties and Manipulation. 9 th ed. Mosby Elsevier 2008; 172-180.

[31]. Junevicius J, Pavilonis A, Surna A. Trasnmission of Microorganisms from Dentist to Dental Laboratory Technicians through Contaminated Dental Impressions. Baltic Dental and Maxillofacial Journal 2004; 6(1) : 20-23. 